\title{
PENGARUH KUALITAS AUDIT TERHADAP KEPUASAN KLIEN
}

\author{
Mika Marsely ${ }^{a}$ \\ Sedianingsih ${ }^{b}$ \\ ${ }^{a}$ Sekolah Pascasarjana Universitas Airlangga ${ }^{b}$ Fakultas Ekonomi dan Bisnis Universitas Airlangga \\ Email:mika.marsely17@gmail.com ${ }^{\mathrm{a}}$; sedianingsih@feb.unair.ac.id ${ }^{\mathrm{b}}$
}

ARTICLE HISTORY

Received:

2 July 2017

Revised

4 August 2017

Accepted:

22 August 2017

Online available:

9 November 2017

Keywords :

audit quality, client satisfaction

\section{ABSTRACT}

The purpose of this research is to examine the effect of audit quality on client satisfaction. The unit of analysis in this study is the PNPM Mandiri Urban LKM in Sidoarjo Regency, amounting to 291 MFIs scattered in all villages / wards in Sidoarjo Regency. PNPM Mandiri Urban LKM is a nonprofit organization that aims to alleviate poverty. The sample in this study consisted of 32 economic village village (faskel) facilitators who overshadowed 291 LKM and also acted as counterpart auditors during the audit. The number of questionnaires distributed was 32 copies and 32 returned questionnaires or as many as $100 \%$. The data analysis technique used in this research is Multiple Linear Regression Analysis.

The results of this study indicate that the understanding attribute of the client industry and responsiveness to client needs has a significant effect on client satisfaction. Meanwhile, the attributes of competence, independence, caution of the audit team, KAP commitment to quality, high ethical standards and skepticism of the audit team did not have a significant effect on client satisfaction. The limitation in this study is that the sample used only comes from one party, namely the auditee. It is recommended that further research should use samples from both parties between the auditee and the auditor so that more valid answers can be obtained. 


\section{LATAR BELAKANG}

PNPM (Program Nasional Pemberdayaan Masyarakat) Mandiri Perkotaan dirancang sebagai gerakan bersama yang terpadu dalam penanggulangan kemiskinan melalui proses pemberdayaan masyarakat. Upaya yang dilakukan pemerintah adalah dengan memberikan pendampingan dan dana bantuan. Bantuan pendampingan ini diwujudkan dalam bentuk penugasan konsultan dan fasilitator untuk mendampingi dan memberdayakan masyarakat agar mampu merencanakan dan melaksanakan program masyarakat untuk menanggulangi kemiskinan di kelurahan masing-masing. Bantuan dana diberikan dalam bentuk dana Bantuan Langsung Masyarakat (BLM).

Selain berkurangnya angka kemiskinan, tujuan dari adanya program ini adalah memberikan pembelajaran good governance kepada masyarakat. Nilai yang terkandung di dalam good governance adalah transparansi, akuntabilitas, dan pengendalian organisasi untuk mencegah terjadinya pengelolaan yang salah dan penyalahgunaan aset. Salah satu cara untuk mewujudkan good governance adalah dengan melakukan audit oleh KAP. Sesuai pedoman pelaksanaan PNPM Mandiri Perkotaan bahwa keterlibatan auditor independen dalam melakukan audit terhadap LKM merupakan bentuk nyata dari masyarakat akan pentingnya penilaian pihak luar untuk membuktikan transparansi dan akuntabilitas. Untuk itu, setiap tahun LKM harus mengauditkan diri kepada auditor independen. Peran auditor adalah sebagai pemeriksa dan pemberi pendapat profesional atas informasi yang dibuat oleh LKM beserta perangkatnya.

Messier et al dalam Yuniarti dan Willy (2013) menyebutkan bahwa permintaan akan jasa audit bisa dipahami sebagai kebutuhan untuk memperoleh akuntabilitas ketika business owners merekrut manajer untuk mengelola bisnisnya. Melalui audit ini, auditor diharapkan mampu memberikan keyakinan secara independen atas akuntabilitas penggunaan dana oleh LKM beserta UP-UP dan pihak pelaksana kegiatan serta untuk mendeteksi adanya kecurangan dan korupsi. Oleh karena itu, kemampuan menyediakan jasa audit yang berkualitas tinggi harus diperhatikan oleh Kantor Akuntan Publik.

Berdasarkan pada uraian di atas, peneliti ingin melakukan sebuah penelitian mengenai pengaruh kualitas audit terhadap kepuasan klien dengan menggunakan studi empiris pada PNPM Mandiri Perkotaan Kabupaten Sidoarjo. Fokus pada penelitian ini adalah audit atas laporan keuangan. Peneliti memilih lokasi penelitian di Kabupaten Sidoarjo karena Kabupaten Sidoarjo merupakan penerima dana PNPM terbanyak dan dengan wilayah terbesar se Indonesia. Dari penelitian ini diharapkan dapat diketahui bagaimana persepsi klien yaitu LKM PNPM Mandiri Perkotaan Kabupaten Sidoarjo terhadap kualitas audit dari para auditornya. Dengan demikian, hasil studi ini dapat berguna bagi klien dalam penilaiannya terhadap kualitas jasa yang digunakan. Juga 
berguna bagi KAP agar dapat membuat strategi pengembangan kualitas auditnya serta pemerintah sebagai pihak pemberi dana.

\section{TINJAUAN PUSTAKA}

\section{Agency Theory (Teori Keagenan)}

Teori keagenan berbicara mengenai hubungan kontraktual antar anggotaanggota dalam perusahaan. Pihak yang berperan dalam hubungan kontraktual tersebut adalah prinsipal dan agen. Prinsipal adalah pihak yang memberikan mandat kepada agen untuk bertindak atas nama prinsipal, sedangkan agen adalah pihak yang diberi amanat oleh prinsipal untuk menjalankan perusahaan. Agen berkewajiban untuk mempertanggungjawabkan apa yang telah diamanahkan oleh prinsipal kepadanya.

Menurut Jensen and Mackling (1976), masalah agensi timbul karena adanya konflik kepentingan antara shareholders dan manajer, karena tidak bertemunya utilitas yang maksimal antara mereka. Sebagai agen, manajer secara moral bertanggung jawab untuk mengoptimalkan para prinsipal, namun di sisi yang lain manajer juga mempunyai kepentingan memaksimumkan kesejahteraan mereka. Sehingga ada kemungkinan besar agen tidak selalu bertindak demi kepentingan terbaik prinsipal.

Menurut Keown dkk (2001:18), masalah keagenan timbul akibat dari pemisahan tugas antara pemegang manajemen perusahaan dengan pemegang saham, karena ada pemisahan antara si pembuat keputusan dan pemilik perusahaan, para manajer bisa saja membuat keputusan yang sama sekali tidak sesuai dengan tujuan memaksimalkan kesejahteraan para pemegang saham. Masalah keagenan akan tetap terjadi kecuali jika struktur insentif yang dibuat mencakup keselarasan kepentingan antara para manajer dan pemegang saham.

Adanya perbedaan kepentingan antara prinsipal dan agen salah satunya disebabkan oleh adanya Asymmetric Information. Menurut Keown dkk (2001:35), Asymmetric Information adalah situasi dimana manajer memiliki informasi yang berbeda (yang lebih baik) mengenai prospek perusahaan daripada yang dimiliki investor. Adanya Asyymetric Information dan self serving behaviour pada manajer atau agen memungkinkan mereka untuk mengambil keputusan dan kebijakan yang kurang bermanfaat bagi perusahaan dan memberikan kesempatan kepada manajer untuk memperoleh keuntungan pribadi.

\section{Kulitas Audit}

Riyatno (2007) menyatakan bahwa kualitas audit merupakan sesuatu yang tidak terlihat dan sulit untuk diukur yang hanya bisa dirasakan oleh pengguna jasa audit sehingga tidak ada keseragaman atas definisi dari kualitas audit. Auditor eksternal yang 
mampu memberikan kualitas jasa yang tinggi dalam organisasi nirlaba dan pemerintahan berarti bahwa auditor tersebut berperan dalam meningkatkan kualitas pelaporan serta mekanisme organisasi dalam memonitor dan mengontrol operasi organisasi (Khurana and Rhaman, 2004).

Catanach and walker (1999) melihat bahwa kualitas audit merupakan fungsi dari kinerja auditor. Mereka berpendapat bahwa kualitas audit dipengaruhi oleh kemampuan dan profesionalitas auditor dalam melakukan pekerjaan audit. Oleh karena itu, kegagalan auditor dalam mendeteksi salah saji material, kecurangan maupun korupsi akan berdampak pada kualitas audit yang rendah. Penelitian ini mengacu pada penelitian sebelumnya yang dilakukan oleh Crcello et al (1992), Bhen et al (1992), Samelson et al (2006), Pamudji (2009), Iskandar et al (2010) dan Yuniarti dan Willy (2013).

\section{Kepuasan Klien}

Kepuasan pelanggan adalah perasaan senang atau kecewa seseorang sebagai hasil dari perbandingan antara prestasi atau produk yang dirasakan dan yang diharapkannya (Kotler, 1997:36). Definisi kepuasan menurut Zeithaml and Bitner (2003:86) adalah: "Satisfaction is the customers evaluation of product or service in terms of whether that product or service has meet their needs and expectations". Dalam rangka menciptakan kepuasan pelanggan, produk/jasa yang ditawarkan organisasi harus berkualitas Kualitas produk yang dirasakan pelanggan akan menentukan persepsi pelanggan terhadap kinerja, yang pada gilirannya akan berdampak pada kepuasan pelanggan.

Sedangkan kualitas jasa audit berhubungan dengan persepsi klien yang diaudit oleh KAP ditandingkan dengan pengharapan klien tersebut. KAP harus memahami bagaimana klien mempersepsikan jasa yang mereka terima. Cronin and Taylor (1992) berpendapat bahwa ketiadaan ukuran yang obyektif dari suatu pendekatan yang tepat untuk melihat kualitas dari suatu perusahaan jasa adalah dengan mengukur kinerja dari jasa yang dikonsumsi oleh konsumen. Dengan demikian, orientasi kepada klien menjadi faktor penting bagi KAP. Cronin and Taylor juga menyimpulkan bahwa kepuasan konsumen akan dipengaruhi oleh tingkat kualitas jasa yang konsumen terima.

\section{Pengaruh Kualitas Audit terhadap Kepuasan Klien}

Menurut Kotler \& Amstrong (2008:7) "Customer satisfaction is closely linked to quality. Quality has a direct impact of product performance and customer satisfaction". Artinya, kepuasan konsumen sangat berkaitan erat dengan kualitas. Kualitas memiliki dampak langsung terhadap performa produk dan kepuasan konsumen. Menurut Stanton, Etzel and Walker (1994:15) "For marketers, the best measures of quality is 
customer satisfaction". Artinya, bagi pemasar, ukuran kualitas yang paling baik adalah kepuasan konsumen.

Kesimpulan dari teori-teori yang menyatakan hubungan antara kepuasan konsumen dengan kualitas pelayanan adalah kepuasan konsumen berhubungan dengan beberapa aspek salah satunya kualitas pelayanan dan sangat berkaitan erat dengan kualitas, karena kualitas merupakan tolak ukur dan indeks dari kepuasan konsumen. Kualitas audit dan kepuasan klien merupakan dua hal penting tapi memiliki konsep yang berbeda dalam bidang audit (Behn et al, 1997). Untuk tetap bertahan, maka KAP harus mampu memberikan kualitas audit dan kepuasan klien dengan level yang tinggi. Kualitas audit merupakan faktor penting baik untuk pihak internal auditee maupun pemegang saham, sedangkan kepuasan klien merupakan inti dari profesi akuntan itu sendiri (Bhattacharya, 2001)

Berdasarkan pada landasan teori dan tujuan studi maka hipotesis dalam penelitian ini adalah:

H1: Pemahaman auditor terhadap industri klien berpengaruh secara signifikan terhadap kepuasan klien pada PNPM Mandiri Perkotaan kabupaten Sidoarjo.

H2: Responsifitas auditor terhapa kebutuhan klien berpengaruh secara signifikan terhadap kepuasan klien pada PNPM Mandiri Perkotaan kabupaten Sidoarjo.

H3: Kompetensi auditor berpengaruh secara signifikan terhadap kepuasan klien pada PNPM Mandiri Perkotaan kabupaten Sidoarjo.

H4: Independensi auditor berpengaruh secara signifikan terhadap kepuasan klien pada PNPM Mandiri Perkotaan kabupaten Sidoarjo.

H5: Sikap hati-hati tim audit berpengaruh secara signifikan terhadap kepuasan klien pada PNPM Mandiri Perkotaan kabupaten Sidoarjo.

H6: Komitmen KAP terhadap kualitas berpengaruh secara signifikan terhadap kepuasan klien pada PNPM Mandiri Perkotaan kabupaten Sidoarjo.

H7: Pelaksanaan audit lapang berpengaruh secara signifikan terhadap kepuasan klien pada PNPM Mandiri Perkotaan kabupaten Sidoarjo.

H8: Standar etika yang tinggi dari tim audit berpengaruh secara signifikan terhadap kepuasan klien pada PNPM Mandiri Perkotaan kabupaten Sidoarjo.

H9: Sikap skeptis tim audit berpengaruh secara signifikan terhadap kepuasan klien pada PNPM Mandiri Perkotaan kabupaten Sidoarjo. 


\section{METODE PENELITIAN}

\section{Rancangan Penelitian}

Penelitian ini adalah termasuk jenis penelitian eksplanasi (explanatory research). Unit analisis yang digunakan dalam penelitian ini adalah Lembaga Keswadayaan Masyarakat (LKM) yang dalam penelitian ini diwakili oleh faskel (fasilitator kelurahan) ekonomi selaku fasilitator pendamping bidang manajemen keuangan serta audit PNPM Mandiri Perkotaan Kabupaten Sidoarjo.

\section{Populasi dan Sampel Penelitian}

Populasi dalam penelitian ini adalah faskel (fasilitator kelurahan) ekonomi yang merupakan counterpart auditor. Faskel ekonomi merupakan fasilitator pendamping LKM dalam bidang manajemen keuangan dan audit. Dalam PNPM Mandiri Perkotaan Kabupaten Sidoarjo terdapat 32 faskel ekonomi yang mendampingi 291 LKM yang tersebar di 291 desa di Kabupaten Sidoarjo. Populasi yang ada dalam penelitian ini seluruhnya dijadikan sampel penelitian, sehingga sampel penelitian juga berjumlah 32 orang.

\section{Definisi Operasional dan Pengukuran Variabel Kualitas Audit (X)}

Menurut SAIs (Supreme Audit Institutions) kualitas audit merupakan sekumpulan karakteristik yang melekat pada pemenuhan persyaratan audit yang diperoleh melalui proses mengidentifikasi dan mengkaji aktivitas-aktivitas yang dibutuhkan untuk mencapai tujuan daripada kualitas audit. Variabel kualitas audit dijabarkan lagi ke dalam 9 sub variabel, diantaranya yaitu pemahaman auditor terhadap industri klien, responsif terhadap kebutuhan klien, kompetensi, independendi, sikap hati-hati tim audit, komitmen KAP terhadap kualitas, pelaksanaan audit lapang, standar etika yang tinggi tim audit dan sikap skeptis tim audit.

\section{Kepuasan Klien (Y)}

Kepuasan klien merupakan tingkat kepuasan yang dirasakan klien berdasarkan hasil evaluasi atas pekerjaan audit secara menyeluruh. Item pertanyaan mengenai kepuasan klien dalam penelitian ini diukur dengan menggunakan skala Likert 1-4. Indikator untuk mengukur kepuasan klien adalah kepuasan terhadap kinerja tim audit. 


\section{Metode Pengumpulan Data}

Metode pengumpulan data yang digunakan dalam penelitian ini adalah dengan menggunakan kuesioner. Sebagai pelengkap data, peneliti akan melakukan wawancara dan dokumentasi yaitu berupa data hasil audit yang telah diterbitkan oleh KAP serta data lain yang relevan terhadap penelitian.

\section{Teknik Analisis Data}

Dari jawaban yang diperoleh dari responden selanjutnya akan dianalisis dengan menggunakan regresi linear berganda. Analisis regresi linear berganda digunakan untuk menjawab hipotesis dalam penelitian ini. Dalam analisis Regresi linear berganda, selain mengukur kekuatan hubungan antara dua variabel atau lebih, juga menunjukkan arah hubungan antara variabel dependen dengan variabel independen.

\section{HASIL PENELITIAN DAN ANALISA}

\section{Pembahasan hipotesis 1 (pemahaman terhadap industri klien)}

Pemahaman terhadap industri klien dinyatakan berpengaruh terhadap kepuasan klien. Pemahaman terhadap industri klien merupakan faktor penting penentu kualitas audit karena auditor bisa mengetahui resiko, peluang dan praktek akuntansi untuk industri klien yang didapatkan selama melakukan pekerjaan audit (Craswell et al, 1995: Hogan and Jeeter, 1999: Solomon et al, 1999: Gramling and Stone, 2001: Velury et al, 2003 dalam Boon et al, 2008).

Hasil penelitian ini konsisten dengan penelitian yang dilakukan oleh Carcello et al, 1992, Bhen et al, 1997, Samelson et al, 2006, dan Boon et al, 2008 yang menyatakan bahwa pemahaman terhadap industri klien merupakan atribut kualitas audit yang paling berpengaruh terhadap kepuasan klien.

Tetapi hal yang sedikit berbeda dinyatakan oleh Iskandar et al (2010) dalam temuan penelitiannya bahwa klien tidak secara khusus mengacu pada pemahaman auditor terhadap industrinya dalam menentukan kepuasan mereka.

\section{Pengujian Hipotesis 2 (responsif terhadap kebutuhan klien)}

Responsif terhadap kebutuhan klien dinyatakan berpengaruh terhadap kepuasan klien. Sesuai dengan pendapat Johnson and Lyss (1990) bahwa salah satu faktor yang membuat klien menjatuhkan pilihannya pada auditor adalah karena kesungguhan auditor tersebut memperhatikan kebutuhan klien.

Hasil penelitian ini konsisten dengan hasil penelitian Carcello et al (1992), Bhen et al (1997), Samelson et al (2006), Boon et al (2008) dan Iskandar et al (2010) yang 
menemukan bahwa responsif terhadap kebutuhan klien merupakan salah satu faktor utama yang menentukan kepuasan klien.

\section{Pengujian Hipotesis 3 (kompetensi)}

Atribut kompetensi dinyatakan tidak berpengaruh secara signifikan terhadap kepuasan klien. Sesuai dengan pendapat Bhen et al (1997) bahwa ada 5 hal yang menjadi dasar dilakukannya audit, yaitu adanya kompetensi teknis, independensi, sikap hati-hati, komitmen terhadap kualitas dan standar etika. Tetapi 5 komponen tersebut tidak berhubungan secara langsung terhadap kepuasan klien seperti komponen-komponen kualitas audit lainnya. Kelima komponen ini dipakai sebagai jaminan dilaksanakannya audit yang berkualitas.

Hasil penelitian ini konsisten dengan penelitian yang dilakukan oleh Bhen et al (1997), Samelson et al (2006), dan Iskandar et al (2010) bahwa kompetensi auditor tidak berpengaruh terhadap kepuasan klien. Samelson et al menemukan bahwa meskipun tim audit secara keseluruhan memiliki kompetensi teknis yang memadai tetapi kontribusinya kecil terhadap kualitas audit yang dipersepsikan oleh klien..

Sebaliknya, hasil temuan ini berkebalikan dengan hasil temuan Boon et al (2008) yang menyatakan bahwa kompetensi berpengaruh positif terhadap kepuasan klien. Menurut Boon et al, staf audit yang memiliki kompetensi teknis sebagai akuntan atau akuntan publik yang bersertifikat tentunya sudah terbiasa dengan standar akuntansi dan auditing dan tentunya juga lebih mampu dalam mendeteksi salah saji yang material. Staf ahli keuangan dan auditor internal (klien) yang menjadi respondennya menyatakan bahwa secara keseluruhan mereka akan merasa lebih puas ketika tim audit memiliki kompetensi teknis yang memadai. Karena kompetensi teknis yang memadai merupakan bagian dari jasa audit yang berkualitas secara keseluruhan.

\section{Pengujian Hipotesis 4 (independensi)}

Atribut independensi dinyatakan tidak berpengaruh secara signifikan terhadap kepuasan klien. Menurut Bhen et al (1997), walaupun auditor yang melaksanakan audit sudah bersikap independen tetapi tidak berpengaruh terhadap kepuasan kliennya, karena klien lebih senang kalau auditor tersebut bisa diajak komunikasi dua arah. Selama ini, masyarakat khususnya anggota LKM dan pengurusnya belum memiliki kesadaran yang lebih akan pentingnya audit.

Hasil penelitian ini konsisten dengan hasil penelitian Bhen et al (1997), dan Samelson et al (2006) yang menemukan bahwa variabel independensi tidak memiliki hubungan atau pengaruh terhadap kepuasan klien. Dalam penelitiannya Samelson et al menemukan bahwa menurut pandangan klien, independensi sebenarnya memiliki pengaruh yang kecil atau bahkan tidak sama sekali selama audit lapang. Hasil penelitian yang berbeda ditemukan oleh Boon et al (2008) dan Iskandar et al (2010) dimana 
independensi memiliki pengaruh yang positif terhadap kepuasan klien. Iskandar et al menemukan bahwa klien mempersepsikan independensi secara langsung mencerminkan kualitas audit. Sedangkan Boon et al menemukan bahwa auditor yang memiliki independensi akan memberikan kualitas audit yang lebih tinggi. Oleh karena itu, klien mempersepsikan bahwa audit secara keseluruhan akan berkualitas jika auditor memiliki independensi.

\section{Pengujian Hipotesis 5 (sikap hati-hati tim audit)}

Atribut sikap hati-hati tim audit dinyatakan tidak berpengaruh secara signifikan terhadap kepuasan klien. Sesuai dengan pernyataan Bhen et al (1997) bahwa sikap hatihati tim audit tidak berhubungan secara langsung terhadap kepuasan klien seperti komponen-komponen kualitas audit lainnya.

Penelitian ini sesuai dengan hasil penelitian Bhen et al (1997) yang menemukan bahwa variabel sikap hati-hati tim audit tidak memiliki pengaruh terhadap kepuasan klien. Bhen et al menyatakan bahwa Sebaliknya, hasil penelitian ini bertentangan dengan hasil penelitian Boon et al (2008) yang menyatakan bahwa sikap hati-hati tim audit berpengaruh terhadap kepuasan klien. Menurut Boon et al klien merasa lebih puas terhadap kualitas jasa audit secara keseluruhan ketika auditor memiliki sikap kehatihatian.

\section{Pengujian Hipotesis 6 (komitmen KAP terhadap kualitas)}

Atribut komitmen KAP terhadap kualitas audit dinyatakan tidak berpengaruh secara signifikan terhadap kepuasan klien. Hasil penelitian ini konsisten dengan hasil penelitian Bhen et al (1997) yang menyatakan bahwa atribut komitmen KAP terhadap kualitas audit tidak berpengaruh secara langsung terhadap kepuasan klien. Menurutnya, atribut ini digunakan sebagai jaminan dilakukannya audit yang berkualitas. Sebaliknya, hasil penelitian ini tidak konsisten dengan penelitian yang dilakukan oleh Boon et al (2008) dan Iskandar et al (2010) yang menemukan bahwa komitmen KAP terhadap kualitas berpengaruh positif terhadap kepuasan klien. Boon et al menemukan bahwa KAP yang memiliki budaya menjaga kualitas disinyalir akan memberikan audit yang berkualitas tinggi. Hal ini tercermin dari tim audit yang diterjunkannya benar-benar menjalankan praktik audit yang berkualitas karena budaya tersebut sudah melekat di dalam dirinya.

\section{Pengujian Hipotesis 7 (pelaksanaan audit lapang)}

Atribut pelaksanaan audit lapang tidak berpengaruh secara signifikan terhadap kepuasan klien. Bhen et al (1997) menyatakan bahwa pelaksanaan audit lapang yang sesuai akan meningkatkan kepuasan klien. Tidak adanya pengaruh ini lebih disebabkan karena ada beberapa klien yang merasa kurang puas dengan audit lapang yang telah 
dilakukan oleh tim audit di PNPM Mandiri Perkotaan Kabupaten Sidoarjo. Rasa tidak puas ini dipicu oleh misalnya ada kejadian dimana auditor A yang melakukan pengecekan administrasi terhadap suatu LKM Y mulai dari awal, tetapi pada saat pengkroscekkan terhadap kegiatan di lapang yang melakukan justru adalah auditor B. Otomatis hal ini akan menyebabkan pengetahuan yang dimiliki oleh auditor $B$ kurang memadai dikarenakan auditor tersebut tidak mengikuti proses audit secara langsung mulai dari awal. Ada lagi kejadian bahwa ada salah satu auditor yang melakukan pengambilan sampel tidak secara acak, tetapi menggunakan sampel yang sebelumnya sudah dipersiapkan. Otomatis bukti yang didapatkan oleh auditor belum bisa dikatakan memadai. Secara umum auditor memang memahami dan memeriksa sistem pengamanan rekening bank, pengelolaan kas tunai di tangan dan inspeksi mendadak kas, namun pemeriksaan terhadap otorisasi transaksi penerimaan dan pengeluaran kas serta sistem pancatatan dan laporan keuangan kurang mendetail.

Hasil penelitian ini tidak konsisten dengan penelitian yang dilakukan oleh Samelson et al (2006), Boon et al (2008) dan Iskandar et al (2010) yang menemukan bahwa pelaksanaan audit lapang mempunyai pengaruh yang positif terhadap kepuasan klien. Samelson et al menemukan bahwa klien lebih senang ketika tim audit melakukan evaluasi atas sistem akuntansi dan pengendalian internal mereka.

\section{Pengujian Hipotesis $\mathbf{8}$ (standar etika yang tinggi dari tim audit)}

Atribut standar etika yang tinggi dari tim audit dinyatakan tidak berpengaruh terhadap kepuasan klien. Bhen et al (1997) juga menyatakan bahwa sikap hati-hati tim audit tidak berhubungan secara langsung terhadap kepuasan klien seperti komponenkomponen kualitas audit lainnya.

Hasil penelitian ini tidak konsisten dengan hasil penelitian Boon et al (2008) dan Iskandar et al (2010) yang menemukan bahwa standar etika yang tinggi berpengaruh terhadap kepuasan klien. Boon et al menemukan bahwa tim audit yang memiliki standar etika yang tinggi akan lebih mampu dalam memberikan jasa audit yang berkualitas. Hal ini tercermin dari kemampuan untuk mendeteksi dan melaporkan temuan kesalahan dan ketidakwajaran serta integritas auditor juga lebih terjaga karena tidak bisa diajak berkompromi selama proses audit.

\section{Pengujian Hipotesis 9 (sikap skeptis tim audit)}

Atribut sikap skeptis tim audit dinyatakan tidak memiliki pengaruh yang signifikan terhadap kepuasan klien. Menurut Bhen et al (1997), klien akan merasa tidak puas apabila auditor yang melakukan tugasnya menaruh kecurigaan yang tinggi terhadap kliennya. Hasil penelitian ini konsisten dengan penelitian Samelson et al (2006) dan Iskandar et al (2010) yang menemukan bahwa tidak ada pengaruh yang positif antara sikap skeptis tim audit terhadap kepuasan klien. Samelson et al menemukan bahwa 
audit yang dilakukan di sektor pemerintah justru memiliki toleransi yang lebih jika dibandingkan dengan audit sektor swasta. Oleh karena itu sikap skeptis tidak terlalu berpengaruh terhadap kepuasan klien. Hasil temuan ini sebenarnya sedikit kontradiktif terhadap standar auditing yang menekankan adanya sikap skeptis auditor untuk menjamin audit yang berkualitas. Iskandar et al menemukan bahwa sebenarnya klien tidak mengharapkan auditor bersikap skeptis untuk memberikan kepuasan kepada mereka, tetapi cukup dengan melakukan audit lapang yang sesuai dan memiliki sikap kehati-hatian yang lebih selama audit berlangsung.

\section{KESIMPULAN}

Hasil uji hipotesis mengenai pengaruh atribut-atribut kualitas jasa audit terhadap kepuasan klien memperlihatkan terdapat 2 atribut kualitas jasa audit yang berpengaruh secara signifikan terhadap kepuasan klien, yaitu pemahaman terhadap industri klien dan responsif terhadap kebutuhan klien dan ada atribut kualitas audit yang tidak berpengaruh terhadap kepuasan klien, yaitu kompetensi, independensi, sikap hati-hati tim audit, komitmen KAP terhadap kualitas, pelaksanaan audit lapang, standar etika yang tinggi serta sikap skeptis tim audit. Secara umum penelitian ini sama dengan penelitian Bhen et al (1997) dengan perbedaan pada hasil penelitian dan sampel penelitian. Pada hasil penelitian yang dilakukan oleh Bhen et al ditemukan bahwa atribut pengalaman audit, memahami industri klien, responsif atas kebutuhan klien, pelaksanaan audit lapang, keterlibatan komite audit dan keterlibatan pimpinan KAP berpengaruh terhadap kepuasan klien

\section{DAFTAR REFERENSI}

Arens, A.A, R.J, Elder and M.S. Beasly. 2008. Auditing and Assurance Services, 12th ed. Pearson Education, Inc.

Arikunto, S. 2006. Prosedur Penelitian: Suatu Pendekatan Praktik. Jakarta: Rineka Cipta. Behn, B. K., J. V. Carcello., D. R. Hermanson. and R. H. Hermanson. 1997. The Determinants of Audit Client Satisfaction among Clients of Big 6 Firms. Accounting Horizons, (March): vol. 11. No. (1), 7-24.

Bhattacharya, A. 2001. Multiculturalism and The Accounting Profession: Enhancing Employee Productivity and Client Satisfaction. National Public Accountant. 46 (3): 13-14.

Boon, K, J. McKinnon, and P.Ross. 2008. Audit Service Quality in Compulsory Audit Tendering, Preparer Perceptions and Satisfaction. Accounting Research Journal. Vol. 21 No.2. 
Carcello, J. V., R. H. Hermanson. and N. T. McGrath. 1992. Audit Quality Attributes: The Perceptions of Audit Partners, Prepares, and Financial Statement Users. Auditing: A Journal of Practice \& Theory 11, (Spring): 1-15.

Catanach Jr. A.H, and P.L. Walker. 1999. The International Debate Over Mandatory Auditor rotation: A conceptual Research Framework. Journal of International Accounting, auditing and Taxation, 8 (1): 43-66.

Craswell, A. T., J. R. Francis, and B. Sneddon. 1995. The Pricing of Initial Audit Engagement: The Effect of Quality Uncertainty. Working Paper, University of Sydney.

Cronin, J.J and S. A. Taylor. 1994. SERVPERF Versus SERVQUAL: Reconciling Performance Based and Perceptions-minus- Expectation Measurement of Service Quality. Journal of Markerting, page 37-45.

DeAngelo, L.E. 1981. Auditor Size and Audit Quality. Journal of Accounting and Economics. Vol. 3, 183-191

Elitzur, R. and Haim Falk. 1996. Planned Audit Quality. Journal of Accounting and Public Policy. Vol. 15:247-269.

Faisal. 2005. Metode Penelitian. Bandung: Alfabeta.

Francis, J.R. 2004. What Do We Know About Audit Quality?. British Accounting Review. 36 (4), 345-368.

Freeman, R.J. and C.D. Shoulders. 2003. Government and Non Profit Accounting: Theory and Practice 7th edition. Englewood. New York: Prentice Hall.

Ghozali, I. 2005. Aplikasi Analisis Multivariate dengan program SPSS. Badan Penerbit Universitas Diponegoro, Semarang.

Governmental Accounting Standards Boards (GASB). 1999. Statement No. $\quad 34 \quad$ Of The Governmental Accounting Standards Board, Basic Financial Statements - and Management Discussion and Analysis-for State and Local Government. Norwalk, CT: Author.

Hurrt, K., Eining, M. and Plumlee, D. 2003. Professional Skepticism: A Model with Implication for Research, Practice and Education. Working Paper, University of Wisconsin. 
Iskandar, T. M., M. M. Rahmat, and H. Ismail. 2010. The Relationship Between Audit Client Satisfaction and Audit Quality Attributes: Case of Malaysian Listed Companies. Int. Journal of Economics and Management 4(1): 155-180.

Jensen, M.C., and W. H. Meckling. 1976. Theory of The Firm: manajerial Behaviour, Agency Cost and Ownership Structure. Journal of Financial and Economics, 3, 305

Johnson, W. B. and T. Lys. 1990. The Market for Audit Service: Evidence from Voluntary Auditor Changes. Journal of Accounting and Economics, 281 - 308.

Jusuf, A. A. 2003. Auditing: Pendekatan Terpadu. Terjemahan. Jakarta: Salemba Empat.

Keown Arthur J., Scott Jr, David E., Martin John D, Petty, J. William. 2001. Dasar-dasar Manajemen Keuangan. Edisi Ketujuh (Terjemahan). Jakarta: Salemba Empat.

Khurana, I.K. and K. K. Raman. 2004. Are Big Four Audits in ASEAN Countries of Higher Quality than Non-Big Four Audits?. Asia-Pasific Journal of Accounting and Economics, 11 (2), 139-166.

Kotler, P. 1997. Manajemen Pemasaran. Jakarta: Prenhallindo.

---------. 2000. Marketing Management: Edisi Milenium, International Edition. New Jersey : Prentice Hall International, Inc.

dan G. Amstrong. 2008. Prinsip-Prinsip Pemasaran Jilid 1. Terjemahan, Edisi 12. Jakarta : Erlangga.

Mautz, R. K. and Hussein A. Sharaf. 1961. The Philosophy of Auditing. AAA, Florida.

Pamudji, S. 2009. Pengaruh Kualitas Audit dan Auditor Baru serta Pengalaman Bagian Akuntansi terhadap Kepuasan dan loyalitas Klien. JAAI. Vol 13 No.2.

Parasuraman, A., V.A. Zeithaml, and L.L. Berry. 1985. A Conceptual Model of Service Quality and Its Implications for Future Research. Journal of Marketing. Vol. 49, 41-50.

Kementerian Pekerjaan Umum Direktorat Jenderal Cipta Karya. 2010. Pedoman Pelaksanaan PNPM Mandiri Perkotaan. Jakarta. 
2012. Petunjuk

Teknis Pengelolaan Keuangan dan Audit Independen LKM PNPM Mandiri Perkotaan. Jakarta.

\section{Petunjuk}

Teknis Pengukuran Kinerja Sekretariat-UPK PNPM Mandiri Perkotaan. Jakarta.

Riduwan, A. Rusyana dan Enas. 2011. Cara Mudah Belajar SPSS 17.0 dan Aplikasi Statistik Penelitian. Bandung: Alfabeta.

Rittenberg, L. E., M.J. Karla and A.G. Audrey. 2010. Auditing a Business Approach 7th edition. South-Western Cengage Learning pp.735.

Riyatno. 2007. Pengaruh Ukuran Kantor Akuntan Publik Terhadap Earnings Response Coefficients. Jurnal Keuangan dan Bisnis vol. 5 no.2.

Samelson, D., S. Lowensohn. and L. E. Johnson. 2006. The Determinants of Perceived Audit Quality and Auditee Satisfaction in Local Government. Journal of Public Budgeting, Accounting \& Financial Management, 18 (2):139-166.

Schroeder, M. S., I. Salomon dan D. Vickrey. 1986. Audit Quality: The Perceptions of Audit Committe Chairpersons and Audit Partners. Auditing: A Journal of Practice and Theory, 5 (2): 86-94.

Stanton W.J., M.J. Etzel., B.J. Walker. 1994. Fundamentals of Marketing, 10th ed. New York: MacGraw-Hill.Inc.

Santoso, S. 2002. Buku Latihan SPSS Statistik Prametrik. Jakarta: PT. Elex Media Komputindo.

Sudarmanto, R. Gunawan. 2005. Analisis Regresi Linear Ganda dengan SPSS. Yogykarta: Graha IImu.

Sugihartono, J. 2009. Analisis Pengaruh Citra, Kualitas, Layanan dan Kepuasan terhadap Loyalitas Pelanggan. Tesis Tidak dipublikasikan, Program Pasca Sarjana Magister Manajemen Universitas Diponegoro.

Sugiyono. 2010. Metode Penelitian Bisnis. Bandung: Alfabeta.

Tatang. 1995. Manajemen dan Usahawan Indonesia. No. 06/Th XXIV/Juni. 
Taylor, S.S and T. T. Baker. 1994. An Assesment of The Relationship Between Service Quality and Customer Satisfaction in The Formation of Consumers Purchase Intentions. Journal of Retailing: 18-29.

Widagdo, R. 2002. Analisis Pengaruh Atribut-Atribut Kualitas Audit Kepuasan Klien. Tesis Tidak dipublikasikan, Program Terhadap Magister Akuntansi Universitas Diponegoro.

Yuniarti, R. dan Willy. 2013. Audit Quality and Audit Client Satisfaction. International Journal of Humanities and Management Sciences (IJHMS) Volume 1.

Zawitri, S. 2009. Analisis Faktor-Faktor Penentu Kualitas Audit yang dirasakan dan Kepuasan Auditee di Pemerintah Daerah. Tesis Tidak Dipublikasikan. Program Pascasarjana Magister Akuntansi Universitas Diponegoro.

Zeithaml, V.A and M. J. Bitner. 2003. Services Marketing: Integrating Customer Focus Across the Firm, 3rd edition. Boston: McGraw Hill/Irwin. 